\title{
A Study on Consumer Perception towards Affordable Housing Loans
}

\author{
Sachin Warade ${ }^{1}$ and Shubhangi Walvekar ${ }^{2}$ \\ Business Head, Dhanvarsha Finvest Ltd., Mumbai, Maharashtra, India \\ Professor, Progressive Education Society's Modern College of Engineering, Pune, Maharashtra, India \\ E-Mail: sachinwarade@rediffmail.com,drspwalvekar@gmail.com
}

\begin{abstract}
This paper is an attempt to reviews literature on customer perception for affordable housing finance. While it is evident that India has a huge shortage of affordable houses it also needs the proper financing system for the home loan customers in lower level income group. People who are in the category of annual gross income up to 5 lakhs per annually are considered as low income group customers in housing loan industry. There is a severe need of funding to this income group when it comes to build their own shelter. Even though many private and government financial institutions have come up with schemes financing the need of low income group; it is always a challenging task for them to understand what customers from this income group are perceived about their home loan need. Very few evidences exist in present literature talking about the customer perception and customer behavior in this category of housing loans. Hence; this paper is focused to find out customers perception and its impact on their interest to purchase affordable housing loan.

Keywords:Marketing of Affordable Housing Loan, Housing Loan Sales, Consumer Perception, Consumer Expectation, Affordable Housing Loan, Housing Finance
\end{abstract}

\section{INTRODUCTION}

It very commonly known that housing has very important role to be played in human life and hence it is kept it very first stage of Maslow's theory of need hierarchy among basic need. Housing has the history of existence in various kinds not only in human life but in very animal on earth since their existence.

Housing will play a significant role in building up the 'smart India' and secure the country's economic growth in this modern and developed era of human civilization. Adequate housing is recognized as the basic parameter for standard of living analysis by the Universal Declaration of Human Rights and the 1966 International Covenant on Economic, Social and Cultural Rights.

It is projected that that; till year 2030, Indian cities would be having nearly 590 million residents. Supply of formal affordable housing accommodations as well as affordable housing loans will be the most severe challenge to be faced by government.

National housing bank have projected the shortage of homes for various categories of income group i.e. Low income group (LIG), 7.41 million,40\%Medium income group (MIG \& Above), 0.82 million, 4\%Economically Weaker Sections (EWS),10.55 million,56\% . The Technical Group on Urban Housing Shortage (2012-17) has secured the total housing shortage at 18.78 million dwelling units of which out of which 96\% relateto the Economically Weaker Sections (EWS) and Low Income Group (LIG) categories. The National Housing Bank (NHB) has estimated a requirement of approximatelyINR 8.5 Lakh crore for construction of affordable housing in slum and non-slum areas. The picture of housing shortage can be projected better with the help of following figure.

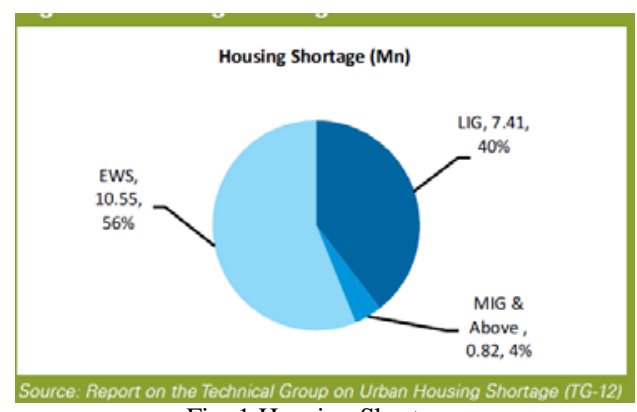

Fig. 1 Housing Shortage

History has evidence that all successive Indian governments have been pre-dominantly promoted affordable housing in country in Indian being in the phase of growth. There is a serious business opportunity driven by organic market forces when it comes to developing housing for all. Even though the private sector is not able to construct affordable housing because of difficulties in land acquisition, high cost of capital, expensive construction techniques, high cost of land, and volatile cost of building material, corruption and scant regulation of the sector the demand for affordable housing clearly exists in India. It is essential that administrative structures and policy frameworks facilitate and encourage resource mobilization from the market and private sector through lucrative policies and bond markets since overall Government resources are limited.

Government of India is also making various schemes to fulfill proposed shortage in housing industry as recently it has set up a vision to provide Housing for All by 2022, Government initiatives like "Atal Mission for Rejuvenation and Urban Transformation” (AMRUT) and Smart City mission is intended to give the necessary fillip to develop an 'Inclusive Urban India'. As per estimates, the vision for “Housing for All by 2022,' would require development of about 11 crore houses with investments of over USD 2 trillion2. The investment plan made by government of India with the help of national housing bank is estimated budget as shown in following table: 
TABLE I INVESTMENT EsTIMATES FOR AFFORDABLE HOUSING

\begin{tabular}{|l|c|c|c|c|c|}
\hline \multicolumn{1}{|c|}{ Units } & $\begin{array}{c}\text { Slum Area } \\
\text { (Million) }\end{array}$ & Non- Slum Area (Million) & $\begin{array}{c}\text { Total } \\
\text { (Million) }\end{array}$ & $\begin{array}{c}\text { Unit Cost } \\
\text { (INR) }\end{array}$ & $\begin{array}{c}\text { Total Cost } \\
\text { (INR crore) }\end{array}$ \\
\hline Need for fresh housing units & 10.61 & 5.68 & 16.29 & $3,50,000$ & $5,70,150$ \\
\hline Incremental housing to address congestion & 4.78 & 7.89 & 12.27 & 60,000 & 76,020 \\
\hline Provision of infrastructure for new housing units & 10.61 & 5.68 & 10.61 & $1,20,000$ & $1,20,320$ \\
\hline Upgradation of infrastructure in existing slums & 10.58 & 0 & 10.85 & 70,000 & 70,000 \\
\hline
\end{tabular}

\section{REVIEW OF LITERATURE}

India had a population accounting 1.21 billion as reported in Indian census 2011. The total number of households was estimated at 33.1 crores for the same year out of which occupied 30.6, residential 23.6, Residential-cum-other uses 0.9 and Non-residential are 6.2 crores. At present India have 1.77 million homeless people in India which counts to the shortage of 18.78 million houses in the country. There is an increase in housing stock in recent decades in the number of households although India has been facing the problem of housing shortage for a long time; and hence, the housing sector and affordable housing loan sector has very huge scope in India. (censusindia.gov.in, 2018)

Krishnamachari (1980) have stated in the National Housing Policy, "Shelter is a basic human need and as an intrinsic part of human settlement, is closely linked with the process of overallsocioeconomic development”. Housing is not only the place of residence but it is the basic accommodation to fulfill most of the social needs of human being. Housing sector is also responsible for employment generation and a parameter to assess country's economic as well as social growth.

Keith and John (1980) presented the new and different image of problems related to housing and said that there is the significant relation between public housing policies and the strategic decisions related to advanced capitalist systems.

Lahiry, S.C (1996) found that there is very severe need of cost control over housing in India as the rising cost of house construction is the biggest threat of household development. He also has highlighted the technology development need for the environment friendly and affordable housing constructions. It is also found in his study that housing industry in our country has undergone very drastic change and developed with very efficient speed in last decade.

Dr K.N. S. Nair and S.G. Jayachandra Raj (1994) have discovered that "Kerala stands unique in the realm of growth and development" still, the state has lost their focus on social sector in the expansion of industrial and technological development.

As it is mentioned inManorama Year Book (1997) "Housing is an integral part of overall policy improvements of human settlements and economic development”. India is in very severe the need of household construction and has very huge shortage in same industry. This problem of housing shortage is also demanding the interference of various public as well as private agencies for the constructive development.

Rangwala (1977), also have endorsed the need of housing in India in similar context stating that; this gap will be taking considerable time span to offer the accommodation to every family of our country. This study also mentioned the need of constructive planning and focused housing targets by government agencies to build better housing in India.

LeelammaKuruvilla (1999) indicated National Housing Policy as well as new initiatives in housing finance. Researcher suggested that the government can think of change in the legal frame-work and simplifying the process for housing finance and the vigorous involvements of the Government in the housing sector will certainly diminish the Indian housing problem.

Bansal, H.S., Taylor, S.F. and James, Y.S., (2005) stated that as the India is showing very rapid economic growth in recent decades; it is very natural that housing loan need in country is going to enhance only. The financial institutions and banking sector has to focus this sector as this need should be catered properly. Government has to identify the potential resource base for the system as a whole and to simplify the legal system with respect to risk management of housing finance institutions.

Teicher.T and Wagenfuhrer. D (2012) have reached to conclusion that, the world financial slag happened in 2008 was the disruptive phase in the global housing sector and had very huge clashes among the housing consumers and financial institutions. The relation between housing loan consumer and financers was badly impacted by this economic reassess.

\section{SCOPE FOR THE STUDY}

The study has very huge scope in order to understand and interpret mindset of existing and proposed customers from affordable housing loan industry. This study will be helpful for marketers of affordable housing loans in order to formulate marketing and selling strategies. As the concept of such loans in private sector financial institutions in our country is not very mature; the study has greater scope to set strong base for the future researches in this sector. 


\section{RESEARCH GAP}

Most of the studies in our country are conducted on housing loans and not on the topic of affordable housing loan. The present literature has highlighted many related studies to this topic in the form of reports by various government and private financial institutions but very few research articles and scripts are published by academicians in the form of research papers and theses. Many research studies in this area are conducted based on the secondary data and hence they are not sufficient to provide the exact understanding of consumer behavior and perception in affordable housing finance industry. Very few articles are available in existing body of knowledge which are talking about the customer opinion for effective marketing channels and their interest to purchase affordable housing loan products. Hence; this research will be an attempt to fulfill the information gap between secondary data reports primary descriptive research.

\section{OBJECTIVES OF THE STUDY}

1. To Study Consumer Belief Towards Affordable Housing Loans.

2. To understand consumer, the effective communication medium to be used in marketing of affordable housing loans.

\section{HYPOTHESIS OF THE STUDY}

1. $\mathrm{H} 0=$ Customer's purchase decisions for affordable housing loan are not dependent on various factors affecting their knowledge about affordable housing finance.

H1 = Customer's purchase decisions for affordable housing loan are significantly dependent on various factors affecting their knowledge about affordable housing finance.

2. $\mathrm{H} 0=$ Customer's purchase decision of affordable housing finance loan is not related to their expected source of funding.

H1= Customer's purchase decision of affordable housing finance loan is significantly related to their expected source of funding.

\section{METHODOLOGY OF STUDY}

This research study is based on the descriptive research design as it is aimed to test stated hypotheses with the help of quantitative techniques and statistical estimations. Primary data was collected from single class of respondents who are considered as customers of affordable housing loan. Many research articles, financial and banking reports, internet sources, marketing books as well as latest news article were searched as secondary sources of information to set research background, objectives and hypotheses for this study. With the help of convenient sampling design; 126 responses were collected measuring customer opinion with qualitative and scale questions. Responses were collected from existing as well as proposed customers for affordable housing loan and coded in the form of numbers in SPSS software to convert them into quantitative form. Nominal, ordinal and Likert scales are used in this study to measure dependent as well as independent variable.

\section{DATA ANALYSIS AND INTERPRETATION}

Data analysis for this research is divided in descriptive and inferential categories as follows: Descriptive analysis:

The survey consists of total 122 respondents out of which most of the respondents were from 30-40 years age group $(81=66.4 \%)$ and very few from less than 30 years group (8=6.6\%) whereas Above 50 year's group was having 7 (5.7\%) and 41-50 years age group has 26 (21.3\%) respondents respectively. Out of 122 respondents 105 (86.1\%) were male and only 17 (13.9) were female. Most of the respondents were from graduation educational qualification group $(78=63.9 \%)$ and $24(19.7 \%)$ from post graduate as well as $20(16.4 \%)$ who did some kind of professional courses. Among selected respondents 86 (70.5\%) people were from salaried group and 36 (29.5\%) were from self-employed profession. Most of the respondents has income close to 5 lakhs per annum (67=54.9\%) whereas $36(29.5 \%)$ people has 200000 lakhs to 300000 and 19 (15.6\%) people has 300001 lakhs to 400000 respectively. 72 (59\%) respondents said that they don't have own house whereas 50 (41\%) has it.

Most of the respondents 43 (35.2\%) were interested in formal loans for their financial need as 29 (23.8\%) respondents has preferred informal loan sources. whereas 24 people (19.7\%) were dependent on employer loan, 17 (13.9\%) expected family help and only 9 respondents (7.4\%) had their personal cash as the source of finance for house. $59 \%$ respondents are still living in rented house. Only $15.6 \%$ respondents have heard about concept of affordable housing finance and $13.9 \%$ are aware about the formalities required for affordable housing loan. Most of the respondents were neutral for the purchase of affordable housing loan i.e. $40.2 \%$. Very few i.e. $8.2 \%$ people are approached by financial institutions in which most common source of information is social media according to $23.8 \%$ respondents. 33.6\% respondents feel to be consulted to friends before they make housing loan decision. $41.8 \%$ respondents preferred 11 to 20 years loan span.

Cross tabulation performed over source of consultation for your financial decisions and interest to buy a home loan have given results as shown below:

It I found that out 122 respondents 28 people agrred that they are interested tobuy homeloan amongs which 10 respondents have consilted with financial professionals and rest with their friends for information need whci is shown in folowing graph. 
TABLE II SOURCE OF CONSULTATION FOR YOUR FINANCIAL DECISIONS AND INTEREST TO BUY A HOME LOAN

\begin{tabular}{|c|c|c|c|c|c|c|c|}
\hline \multicolumn{8}{|c|}{ Count } \\
\hline & & \multicolumn{6}{|c|}{ 9. Interested to buy a home loan } \\
\hline & & $\begin{array}{c}\begin{array}{c}\text { Strongly Dis } \\
\text { Agree }\end{array} \\
\end{array}$ & $\begin{array}{c}\text { Dis } \\
\text { Agree }\end{array}$ & Neutral & Agree & $\begin{array}{c}\text { Strongly } \\
\text { Agree }\end{array}$ & Total \\
\hline \multirow{5}{*}{$\begin{array}{l}\text { 11. Source of } \\
\text { consultation } \\
\text { for your } \\
\text { financial } \\
\text { decisions }\end{array}$} & Relatives & 9 & 0 & 8 & 0 & 0 & 17 \\
\hline & Friends & 0 & 7 & 25 & 9 & 0 & 41 \\
\hline & Expert advice & 0 & 0 & 0 & 9 & 0 & 9 \\
\hline & Internet & 0 & 0 & 16 & 0 & 0 & 16 \\
\hline & Financial professionals & 29 & 0 & 0 & 0 & 10 & 39 \\
\hline \multicolumn{2}{|r|}{ Total } & 38 & 7 & 49 & 18 & 10 & 122 \\
\hline
\end{tabular}

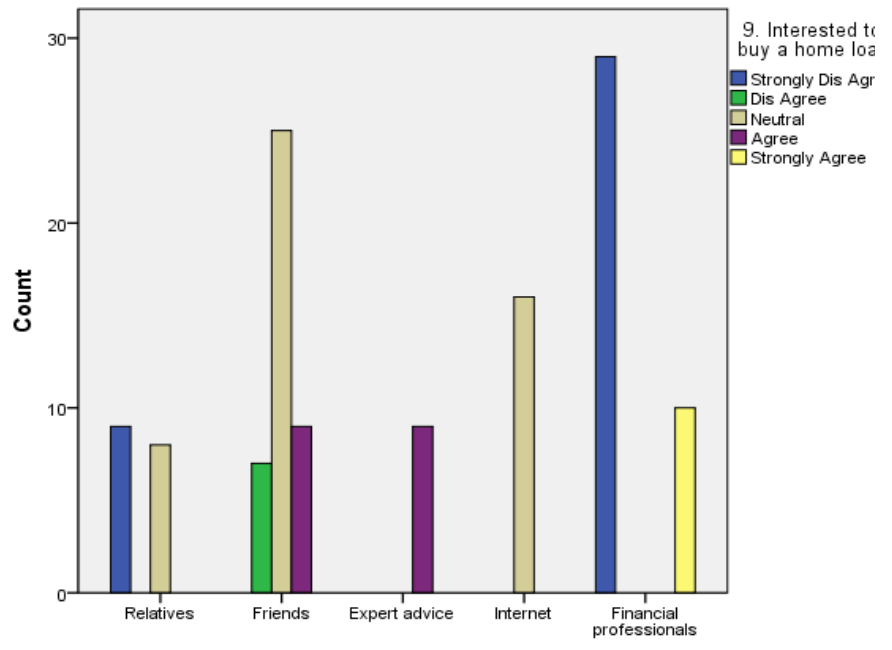

Fig. 2 Source of consultation for your finacial decisions

Cross tabulation performed over source of information about affordable home loans and interested to buy a home loan disclosed that social media and hoardings are better effective communication medium through which customers of affordable housing loan.

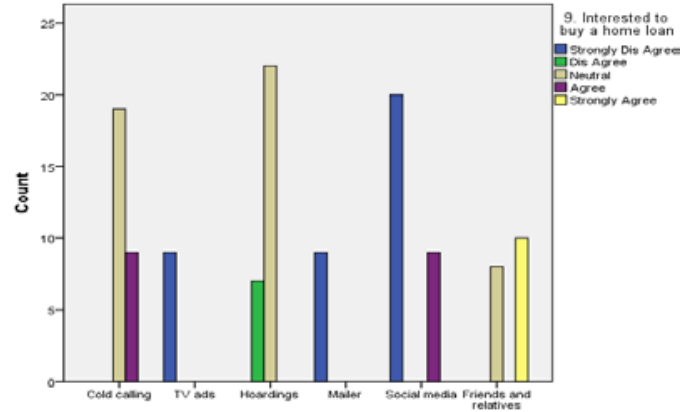

Fig. 3 Source of information about Affordable home

1. H0= Customer's purchase decisions for affordable housing loan are not dependent on various factors affecting their knowledge about affordable housing finance.

H1= Customer's purchase decisions for affordable housing loan are significantly dependent on various factors affecting their knowledge about affordable housing finance.

\begin{tabular}{|c|c|c|c|c|c|c|c|}
\hline & & \multicolumn{6}{|c|}{ 9. Interested to buy a home loan } \\
\hline & & Strongly Dis Agree & Dis Agree & Neutral & Agree & Strongly Agree & Total \\
\hline \multirow{6}{*}{$\begin{array}{l}\text { 10. Source of } \\
\text { information } \\
\text { about } \\
\text { affordable } \\
\text { home loans }\end{array}$} & Cold calling & 0 & 0 & 19 & 9 & 0 & 28 \\
\hline & TV ads & 9 & 0 & 0 & 0 & 0 & 9 \\
\hline & Hoardings & 0 & 7 & 22 & 0 & 0 & 29 \\
\hline & Mailer & 9 & 0 & 0 & 0 & 0 & 9 \\
\hline & Social media & 20 & 0 & 0 & 9 & 0 & 29 \\
\hline & Friends and relatives & 0 & 0 & 8 & 0 & 10 & 18 \\
\hline \multicolumn{2}{|c|}{ Total } & 38 & 7 & 49 & 18 & 10 & 122 \\
\hline
\end{tabular}

The relation between customer's purchase decisions for affordable housing loan and their knowledge about affordable housing finance loan is tested with the correlation test for statistical significance and it is found that there is strong significant positive correlation between customer's purchase decisions for affordable housing loan and Aware about tax benefit on a home loan and
Approached by companies. But there is no correlation between customer's purchase decisions for affordable housing loan and Aware about the formalities of affordable home loans. Expected value of correlation test was $+/-1$ and observed values are $.534^{* *}, .826 * *$ and $.630 * *$ at significance of less than 0.05 levels. So we reject the null hypothesis. 
TABLE IV CORRELATIONS

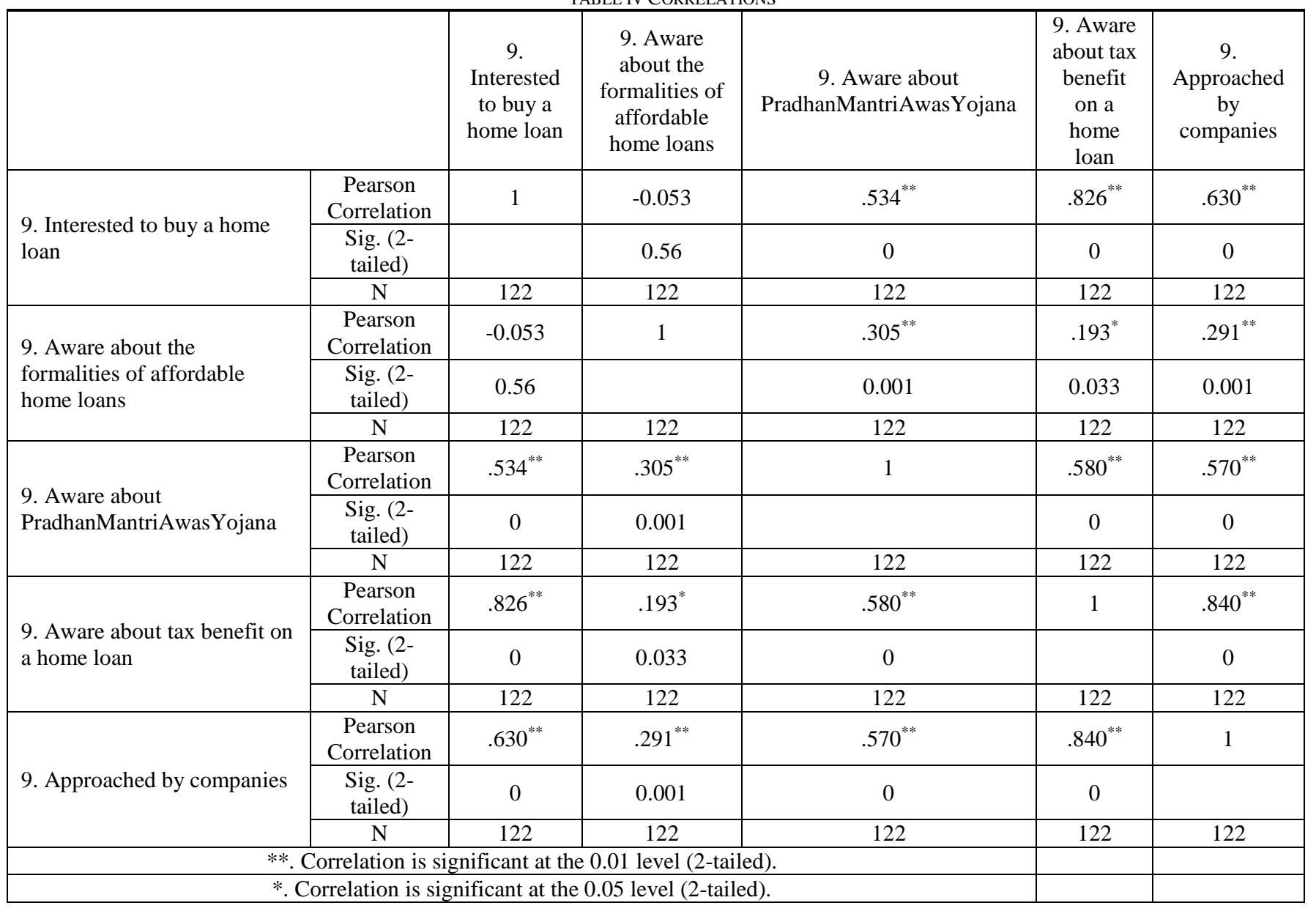

2. H0= Customer's purchase decision of affordable housing finance loan is not related to their expected source of funding. $\mathrm{H} 1=$ Customer's purchase decision of affordable housing finance loan is significantly related to their expected source of funding.

\begin{tabular}{|c|c|c|c|}
\hline \multicolumn{4}{|c|}{ TABLE VCORRELATIONS } \\
\hline & & 9. Interested to buy a home loan & 7. Major source of funds \\
\hline \multirow{3}{*}{ 9. Interested to buy a home loan } & Pearson Correlation & 1 & $.506^{* *}$ \\
\hline & Sig. (2-tailed) & & 0 \\
\hline & $\mathrm{N}$ & 122 & 122 \\
\hline \multirow{3}{*}{ 7. Major source of funds } & Pearson Correlation & $.506^{* *}$ & 1 \\
\hline & Sig. (2-tailed) & 0 & \\
\hline & $\mathrm{N}$ & 122 & 122 \\
\hline \multicolumn{4}{|c|}{ **. Correlation is significant at the 0.01 level (2-tailed). } \\
\hline
\end{tabular}

The correlation test performed to test null hypothesis stating that customer's purchase decision of affordable housing finance loan is not related to their expected source of funding resulted is significant correlation value in the expected range of $+/-1$ and $50.6 \%$ correlation is found among test variables. Hence the null hypothesis is rejected.

\section{FINDINGS AND CONCLUSION}

It is found that even though most of the people from low income group are aware about home loan they are not well educated and communicated about the formalities ad information related to such kind of loans. Most of the people are still dependent on the informal loans for their own house dreams. People in this income group are yet not targeted sufficiently by housing loan companies and this segment is yet waiting for better services. Individuals in this low income group are well literate and have access to all social media and hence they obtained most of the information from there about affordable housing loan. So it to note to banking and financial institutions in our country that there is huge business opportunity and need of 
affordable housing loan segment targeting low income group customers.

\section{REFERENCES}

[1] Krishnamachar S M (1980). Mobilization of Finance for Rural Housing. Yojana Publication Division. New Delhi, 26, 6-18.

[2] Basset Keith, JohnR.\& Paul Kegam (1980). Housing and Residental Structure - Alternatives Approaches, Boston and Henley.

[3] Lahiri, S.C (1996). Rural Housing-An Overview,Kurukshetra.

[4] Dr. Nair K.N.S. \&Jayachandra Raj. (1994). Housingdemandin Kerala by 2001. A.D. Kerala calling.the authoritative English monthly of the Government of Kerala, 5-7.

[5] Manorama Year Book (1992) S.D. Gorangadi-General Manager Housing Bank. Bombay. Focus on Housing - Shelter for Millions. Do you have the money?. 381.

[6] Rangwala S.C. (1977) Town Planning R.C. Patel, Charotar Book Stall, 51-61.

[7] Mrs. LeelammaKuruvilla. (1999). Housing Finance in India. Indian Commerce Bullettin, September. 95 - 98.

[8] Bansal, H.S., Taylor, S.F. \& James, Y.S., 2005. Migrating to New Service Providers: Toward a Unifying Framework of Consumers' Switching Behaviors. Journal of the Academy of Marketing Science.33(1). 96-115

[9] Teichert, T. \& Wagenführer, D. (2012). Effects of Disruptive Events on Consumer Loyalty: Bank Switching After 2008's Crisis.Journal of Business and Policy Research.7(3). 195 - 205.
[10] Lohani. M.B and Bhatia. P (2011). Assessment of Service Quality in Publicand Private Sector banks of India with special reference to Lucknow City.International Journal of Scientific and Research Publications, 2(10). 1-7.

[11] Islam. M.A, Khadem. M.K \& Alauddin.M. (2011). An EmpiricalAssessment of the Relationship between Service Quality and CustomerSatisfaction in Fashion House.Proceedings of the International Conferenceon Industrial Engineering and Operations Management, Kuala Lumpur,Malaysia,

[12] UdayaBhaskar. N and Raja Shekhar. B. (2011). Assessment of servicequality in apparel retailing, A study of three selected cities.Asian Journal of Management Research, 2(1).24-34.

[13] Gradeyan. R.A \& Gbonda.O.O.A (2011). Customers' preference for E-Banking Services: A Case Study of Selected Banks in Sierra Leone. Australian Journal of Business and Management Research. 1(4).108-116.

[14] http://bankingfrontiers.com/focus-is-on-affordable-housing/

[15] https://realty.economictimes.indiatimes.com/news/alliedindustries/art-affordable-housing-finance-to-infuse-over-rs-100-crorefor-expansion-in-fy-18-19/63334232

[16] https://www.tandfonline.com/doi/abs/10.1080/02673039982560

[17] https://www.livemint.com/Politics/hDaqc3PfHKRkaFiv6ov0EP/Amarket-solution-to-affordable-housing.html

[18] http://censusindia.gov.in/2011census/hlo/hlo_highlights.html 